\title{
Agriculture, food and environment during Merovingian times: plant remains from three early medieval sites in northwestern Switzerland
}

\author{
Christoph Brombacher $\cdot$ Dominique Hecker
}

Received: 29 May 2013/Accepted: 16 April 2014/Published online: 5 May 2014

(C) Springer-Verlag Berlin Heidelberg 2014

\begin{abstract}
There have been only a few archaeobotanical investigations of early medieval sites in Switzerland (5th7th century AD) until now. Recent archaeobotanical studies of plant macroremains from three Merovingian settlements in the Canton du Jura, northwest Switzerland, have added to our knowledge of past landscapes, agriculture and food. One was located within an intra-Jurassic basin while the others were situated in the Ajoie plain to the northwest of the Jura mountains. The principal cultivated cereals were Avena sativa, Triticum aestivum, T. spelta and T. monococcum, followed by smaller frequencies of Hordeum distichon/vulgare, Secale cereale and T. dicoccon. Two types of millet, Panicum miliaceum and Setaria italica, were found only sporadically. Legumes such as Lens culinaris, Pisum sativum and Vicia faba were also regularly present in these settlements. Finds of cultivated vegetables and spices like Coriandrum sativum, Apium graveolens and Anethum graveolens were rare. These records, together with those of Malus sp. (probably cultivated) and Prunus domestica, demonstrate the past existence of gardens and orchards. Isolated remains of Juglans regia were also recovered. At Develier-Courtételle, with its partially waterlogged sediments, finds of Linum usitatissimum and Cannabis sativa, together with dyeing and carding plants such as Reseda luteola, Xanthium strumarium and
\end{abstract}

Communicated by F. Bittmann.

Electronic supplementary material The online version of this article (doi:10.1007/s00334-014-0460-4) contains supplementary material, which is available to authorized users.

C. Brombacher $(\bowtie) \cdot$ D. Hecker

Institute for Prehistory and Archaeological Science, University

of Basel, Spalenring 145, 4055 Basel, Switzerland

e-mail: christoph.brombacher@unibas.ch
Dipsacus sativum/fullonum underline the importance of textile production. Among the wild plants found, many taxa are from cultivated fields, meadows and pasture land. Most of these are typical of rather damp, calcareous soils. Plants characteristic of dry grassland are rare, despite this habitat being widely present in the Jura until the first half of the 20th century. Compared to other contemporary sites in Switzerland, northeastern France and southern Germany, only small differences in the spectra of crop plants from the 4 th to the 6th century AD are detected. However the relative proportions of these crop plants vary quite significantly, which could indicate that the significance of the individual taxa at the studied sites differed.

Keywords Canton of Jura - Migration period . Waterlogged macroremains - Cultivated plants . Arable weed flora

\section{Introduction}

This paper deals with the archaeobotanical investigations of three early medieval sites in the Canton of Jura, in northwestern Switzerland. All of these sites were investigated ahead of the construction of the A16 motorway that links Delémont (Canton du Jura, Switzerland) with Montbéliard (Département du Doubs, France). The excavations were carried out by the Section d'Archéologie, Office de la Culture du Canton du Jura. One site (Develier-Courtételle) is situated within the intra-Jurassic basin at Delémont (surface ca. $100 \mathrm{~km}^{2}$ ), while the other two are located within the Ajoie plain to the north of the Jura mountains (Fig. 1). The latter area belongs to the so-called "tabular Jura", which in the north opens onto the Rhine plain and in the west faces towards the Bourgogne (Burgundy) region. 


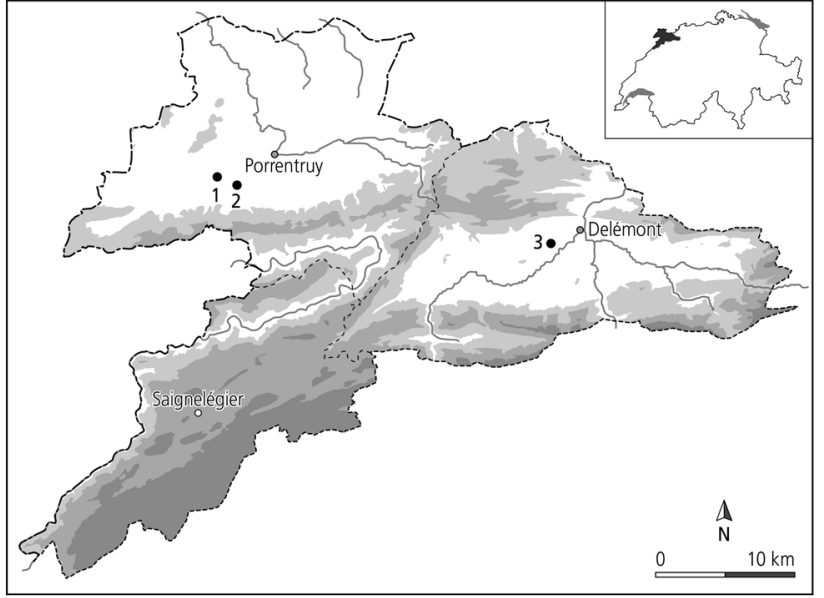

Fig. 1 Site map with the position of the investigated sites in the Canton du Jura. Inset location of Switzerland. 1 Chevenez-Lai Coiratte; 2 Courtedoux-Creugenat; 3 Develier-Courtételle

The Canton du Jura is characterised by a sub-oceanic (maritime temperate) climate with occasional heavy rainfall. Annual precipitation is about $1,000-1,200 \mathrm{~mm}$ in the intra-Jurassic region and about $900-1,000 \mathrm{~mm}$ in the Ajoie plain. The mean annual temperature is between 8 and $9{ }^{\circ} \mathrm{C}$ (Kirchhofer 1982). This climate favours the growth of Fagus sylvatica (beech) with frequent Abies alba (fir) in the montane zone, forming a mixed forest of broadleaf trees and conifers (Abieti-Fagetum) that is widely present up to the submontane zone at 1,000-1,200 m (Ellenberg and Leuschner 2010; Moor 1952).

The main aims of this paper are to provide an insight into the cereal growing economy and other agropastoral activities during the Merovingian period at the three sites and to compare these results with other contemporary sites in west-central Europe north of the Alps. Several aspects of the evolution of the natural vegetation during early medieval times will also be described for the same region.

\section{The sites}

\section{Develier-Courtételle}

The early medieval settlement at Develier-Courtételle is located on the banks of the stream known as La Pran, at an altitude of $440 \mathrm{~m}$ in the Delémont basin, within the Swiss part of the Jura mountains. In 1987, a campaign of archaeological test trenching in advance of the construction of the A16 motorway led to the discovery of this rural settlement.

Excavation of an area of 35,000 $\mathrm{m}^{2}$ between 1993 and 1996 exposed a site dating to the 5th-7th centuries AD (Federici-Schenardi and Fellner 2004). The continuous presence of a stream led to the Merovingian levels being well preserved, with several distinct sedimentary phases that included waterlogged deposits.

Six different farmsteads and four activity areas have been identified, strung out along the banks of the stream. All the activity areas are located outside of the farmsteads and are partly associated with iron working. Three artificial basins were probably used to soak construction timbers, while a textile production area lying directly next to the stream also seems to have depended upon the use of water.

Various scientific studies were carried out, including the analysis of pollen, sediments and animal bones (Guélat et al. 2008). Thanks to the sporadic presence of waterlogged sediments, a great number of waterlogged plant remains were preserved, greatly enriching the spectrum of taxa recovered from the non-waterlogged deposits.

\section{Courtedoux-Creugenat}

The early medieval site of Courtedoux-Creugenat is located within the Ajoie region at an altitude of $448 \mathrm{~m}$ (Fig. 1). It lies on the northern slopes of a small valley, $400 \mathrm{~m}$ downstream of a vertical karstic shaft, from which overflow from an underground river periodically spills today.

This habitation site was discovered in 1999 during a campaign of test excavations undertaken in advance of construction of the A16 Transjuran motorway. An area of $7,500 \mathrm{~m}^{2}$ was excavated between 2000 and 2002 under the direction of C. Deslex.

This settlement was a hamlet made up of a dozen large buildings and 13 sunken-floored huts, which developed rapidly during the 7 th century AD. There are many signs of activities linked with textile production (spindle whorls, needles) and the archaeological material shows close parallels to that of the site at Develier-Courtételle.

In parallel with the archaeobotanical analysis (Hecker 2013), investigations of the animal bones and the sediments were also carried out (Evéquoz et al. 2013). A study of the pollen unfortunately failed to provide useful results as the grains were too corroded.

\section{Chevenez-Lai Coiratte}

The site is situated about $1 \mathrm{~km}$ west of Courtedoux-Creugenat at an altitude of $457 \mathrm{~m}$ within the Ajoie region.

An area of 5,900 $\mathrm{m}^{2}$ was excavated between 2001 and 2002 under the direction of Cécile Bélat-Gonda and Emmanuelle Evéquoz, also ahead of construction of the A16 Transjuran motorway (Evéquoz et al. 2007). This zone lies within a plain crossed by a flood overspill channel.

Various structures linked with metal working were located at the margins of a depression created by successive flood events. The natural slope of the terrain had 
unfortunately encouraged erosion of the archaeological levels, which were only preserved over ca. $1,000 \mathrm{~m}^{2}$. The pottery and metal objects could be attributed to the 6th-7th centuries $\mathrm{AD}$, confirmed by radiocarbon dating.

\section{Materials and methods}

A total of 101 samples with a combined volume of 2041 were analysed from Develier-Courtételle. They were taken from six different farmsteads and other activity areas located outside the buildings. Fireplaces, sunken-floored huts, pits and archaeological layers were mainly sampled (Table 1). In all, 14 samples originated from waterlogged deposits, and the remainder were from dry sediments with aerobic conditions.

At Courtedoux-Creugenat and Chevenez-Lai Coiratte, all plant remains derived from dry sediments. They were recovered exclusively (Courtedoux-Creugenat) or predominantly (Chevenez-Lai Coiratte) from sunken-floored huts as well as from furnace structures. About 450 samples (847 1) were analysed from the former site and 83 (767 1) from the latter. Despite the much greater volumes of processed sediment, the plant assemblages from Courtedoux-Creugenat and Chevenez-Lai Coiratte proved to be considerably poorer than those of DevelierCourtételle.

Table 1 List of investigated samples, grouped by type of feature

\begin{tabular}{|c|c|c|c|}
\hline Site & $\begin{array}{l}1, \\
\text { Chevenez- } \\
\text { Lai } \\
\text { Coiratte }\end{array}$ & $\begin{array}{l}2, \\
\text { Courtedoux- } \\
\text { Creugenat }\end{array}$ & $\begin{array}{l}3, \\
\text { Develier- } \\
\text { Courtételle }\end{array}$ \\
\hline No. of samples & 83 & 450 & 101 \\
\hline $\begin{array}{l}\text { Vol. of samples } \\
\text { (l) }\end{array}$ & 767 & 847 & 204 \\
\hline Preservation & Carbonised & Carbonised & Carb./waterlogged \\
\hline $\begin{array}{l}\text { Archaeological } \\
\text { layer }\end{array}$ & & & 18 \\
\hline $\begin{array}{l}\text { Sunken-floored } \\
\text { hut }\end{array}$ & 33 & 450 & 15 \\
\hline Post hole & 16 & & 11 \\
\hline Oven & & & 2 \\
\hline Fireplace & & & 27 \\
\hline $\begin{array}{l}\text { Combustion } \\
\text { area }\end{array}$ & & & 1 \\
\hline Ditch & & & 1 \\
\hline Furnace & 34 & & 4 \\
\hline Forge & & & 2 \\
\hline Pit & & & 12 \\
\hline Well & & & 2 \\
\hline Other structure & & & 6 \\
\hline
\end{tabular}

Wet-sieving was used to recover the plant macroremains (Pearsall 2000, see also Hosch and Zibulski 2003). The samples were washed through a series of sieves, with mesh sizes of 2, 0.5 and $0.25 \mathrm{~mm}$ for Develier-Courtételle and 8 , 5, 3, 1, 0.5 and $0.25 \mathrm{~mm}$ for Chevenez-Lai Coiratte and Courtedoux-Creugenat. After sieving, the samples that only contained carbonised material were dried in the open air and the residues stored in plastic bags until they were sorted for charred botanical remains. The residues from the waterlogged samples were stored wet until they were sorted. Seeds and other identifiable plant remains were picked out of the residues and then identified using a low power binocular microscope with $6 \times$ to $30 \times$ magnification. The identification of these plant remains was based upon their morphological characteristics, using reference collections belonging to the Institute for Prehistory and Archaeological Science (IPAS) at Basel University and specialist literature (Cappers et al. 2006).

For the analysis of some dried, grain-rich sample residues from Develier-Courtételle, we divided the material with the help of a riffle box (Van der Veen and Fieller 1982). The volumes of the subsamples were measured and the counts for all taxa were then multiplied to correspond to the total volume for all fractions. The plant taxa identified from the sites (ESM 1) were grouped according to their use and their modern-day phytosociological and ecological behaviour (Ellenberg 2001).

\section{Results}

The plant remains from Develier-Courtételle

In Develier-Courtételle a total of 61,422 plant macroremains representing 241 different taxa were recorded. About $61 \%$ of the plant remains were charred, $38 \%$ were waterlogged and $1 \%$ mineralised. Densities of plant material in the samples were very variable. Samples taken in waterlogged contexts had concentrations between 54 and 2,371 items per litre, whereas only a few samples from dry sediments delivered notable concentrations, like those from the sunken huts and from the archaeological layer.

The great majority of cultivated plants were cereals, and nine taxa were identified. Most of these 21,092 remains were charred cereal grains (74\%), while just $26 \%$ represented chaff material, including some waterlogged remains from Develier-Courtételle (Table 2).

The most abundant cereal was Avena sp. (oat), followed by Triticum spelta (spelt) and T. monococcum (einkorn) (Fig. 2). There were only limited proportions of Secale cereale (rye), Hordeum vulgare (barley), Panicum 
Table 2 Cultivated and useful plant remains found at the three sites (see Fig. 1)

\begin{tabular}{|c|c|c|c|c|c|}
\hline Site & & 1 & 2 & 3 , carb. & 3 , waterl. \\
\hline \multicolumn{6}{|l|}{ Cereals } \\
\hline Avena sativa & Chaff, floret & 1 & 205 & 309 & 2 \\
\hline A. sativa/sp. & Grain & 605 & 434 & 11,636 & \\
\hline Cerealia & Chaff/grain, pericarp & $22 / 2,314$ & $223 / 1,130$ & $563 / 1,701$ & $9 / 19$ \\
\hline Hordeum cf. distichon/vulgare & Chaff & & 5 & 5 & \\
\hline H. distichon/vulgare & Grain & 13 & & 254 & \\
\hline Paniceae & Grain & & 1 & 1 & \\
\hline Panicum miliaceum & Grain & 3 & 2 & 2 & \\
\hline Secale cereale & Chaff/grain & $12 / 56$ & $93 / 31$ & $122 / 14$ & $108 /$ \\
\hline Setaria italica & Grain & & 2 & & 1 \\
\hline Triticum aestivum & Chaff/grain & $84 / 421$ & $276 / 211$ & $59 / 134$ & 3 \\
\hline T. dicoccon & Chaff/grain & $/ 1$ & $2 / 12$ & $28 / 133$ & 9/ \\
\hline T. dicoccon/spelta & Chaff/grain & & $3 /$ & $133 / 11$ & $10 /$ \\
\hline T. monococcum & Chaff/grain & $/ 1$ & $23 / 6$ & $569 / 602$ & $97 /$ \\
\hline T. monococcum/dicoccon & Grain & & 1 & & 8 \\
\hline T. spelta & Chaff/grain & $71 / 6$ & $155 / 54$ & $3,004 / 390$ & $379 /$ \\
\hline Triticum sp. & Chaff/grain & $15 / 511$ & $210 / 434$ & $18 / 728$ & $27 / 4$ \\
\hline \multicolumn{6}{|l|}{ Pulses } \\
\hline Fabaceae (cultiv.) & Seed & & & 165 & 3 \\
\hline Lens culinaris & Seed & 137 & 17 & 9 & \\
\hline Pisum sativum & Seed & & & 1 & \\
\hline Vicia sativa & Seed & 2 & & 29 & \\
\hline \multicolumn{6}{|l|}{ Oil/fibre plants } \\
\hline Camelina sativa & Seed & & & & 16 \\
\hline Cannabis sativa & Seed & & & & 44 \\
\hline Linum usitatissimum & Capsule/seed & 17 & & $/ 25$ & $543 / 484$ \\
\hline Papaver somniferum & Seed & & & 1 & 4 \\
\hline \multicolumn{6}{|l|}{ Vegetables/spices } \\
\hline Anethum graveolens & Fruit & & 4 & 1 & 5 \\
\hline Apium graveolens & Fruit & & & & 1 \\
\hline Brassica nigra & Seed & & 1 & & \\
\hline Brassica sp. & Seed & 1 & 6 & 12 & 7 \\
\hline Coriandrum sativum & Fruit & 1 & 1 & 5 & \\
\hline Humulus lupulus & Seed & & & 1 & 232 \\
\hline Thymus sp. & Fruit & & & & 5 \\
\hline \multicolumn{6}{|l|}{ Fruits/nuts, dye plants and others } \\
\hline Atropa bella-donna & Seed & 4 & 11 & & 4 \\
\hline Claviceps sp. & Sclerotium & & & 3 & \\
\hline Corylus avellana & Fruit & 35 & 88 & 12 & 19 \\
\hline Dipsacus sativus/fullonum & Fruit & & & 3 & 2 \\
\hline Fagus sylvatica & Seed & & & & 69 \\
\hline Fragaria vesca & Fruit & & 2 & 3 & 141 \\
\hline Juglans regia & Fruit & & 14 & & \\
\hline Malus sp. & Pericarp/seed & & 16 & 12 & $8 / 1$ \\
\hline Prunus domestica & Fruit & 4 & & 1 & \\
\hline P. domestica/insititia/spinosa & Fruit & 69 & & & \\
\hline Prunus sp. & Fruit & & 13 & 3 & \\
\hline P. spinosa & Fruit & & & & 7 \\
\hline Reseda luteola & Seed & & & & 2 \\
\hline Rubus fruticosus & Seed & 1 & & 2 & 89 \\
\hline R. idaeus & Seed & 1 & 2 & 15 & 143 \\
\hline Sambucus ebulus & Seed & 34 & 90 & 8 & 154 \\
\hline S. nigra/racemosa & Seed & 2 & & & 13 \\
\hline Sambucus sp. & Seed & 2 & 120 & 11 & 104 \\
\hline Stachys officinalis & Fruit & & 1 & & \\
\hline Xanthium sp. & Fruit & & 2 & & \\
\hline X. strumarium & Fruit & & & & 116 \\
\hline Total & & 4,436 & 3,891 & 20,728 & 2,892 \\
\hline
\end{tabular}

miliaceum (broomcorn millet), Setaria italica (Italian millet), $T$. aestivum (bread wheat) and $T$. dicoccon (emmer).

Besides cereals, uncarbonised seeds of Linum usitatissimum (flax) and Cannabis sativa (hemp) were abundant, especially in the waterlogged deposits. Papaver somniferum (opium poppy), Brassica sp. (cabbage, etc.) and Camelina sp. (gold of pleasure) (nearly all waterlogged), on the contrary, were rare. Among the pulses, only a few carbonized remains of Lens culinaris (lentil) and 


\section{Courtedoux-Creugenat $(n=2,147)$}

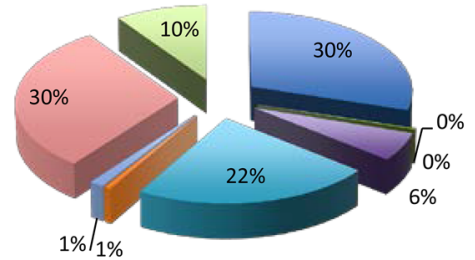

Develier-Courtételle $(n=18,715)$

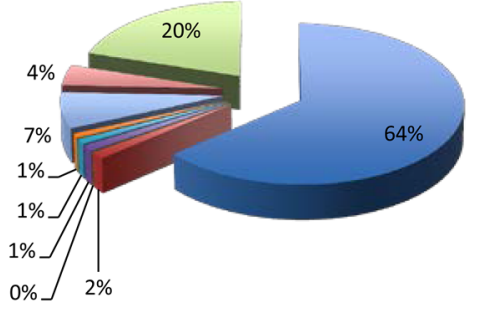

Chevenez-Lai Coiratte $(n=1,797)$

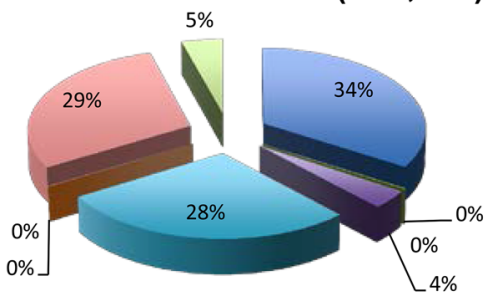

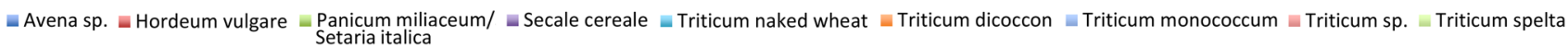

Fig. 2 Proportion of the charred cereal remains (based on the number of grains and chaff)

Pisum sativum (pea) were found. Vegetables and spices were represented by carbonized mericarps of Coriandrum sativum (coriander) and both waterlogged and carbonized mericarps of Anethum graveolens (dill). Both spices were probably cultivated in gardens.

Of special interest are the more than 200 waterlogged seeds of Humulus lupulus (hop) that were found in waterlogged sediments, together with pollen evidence of Humulus-Cannabis-type (Wick 2008). In addition, two plant species used for dyeing were found, Reseda luteola (weld) and Xanthium strumarium (rough cocklebur). Furthermore, remains of Dipsacus fullonum (wild teasel) were identified, which was used for carding and textile

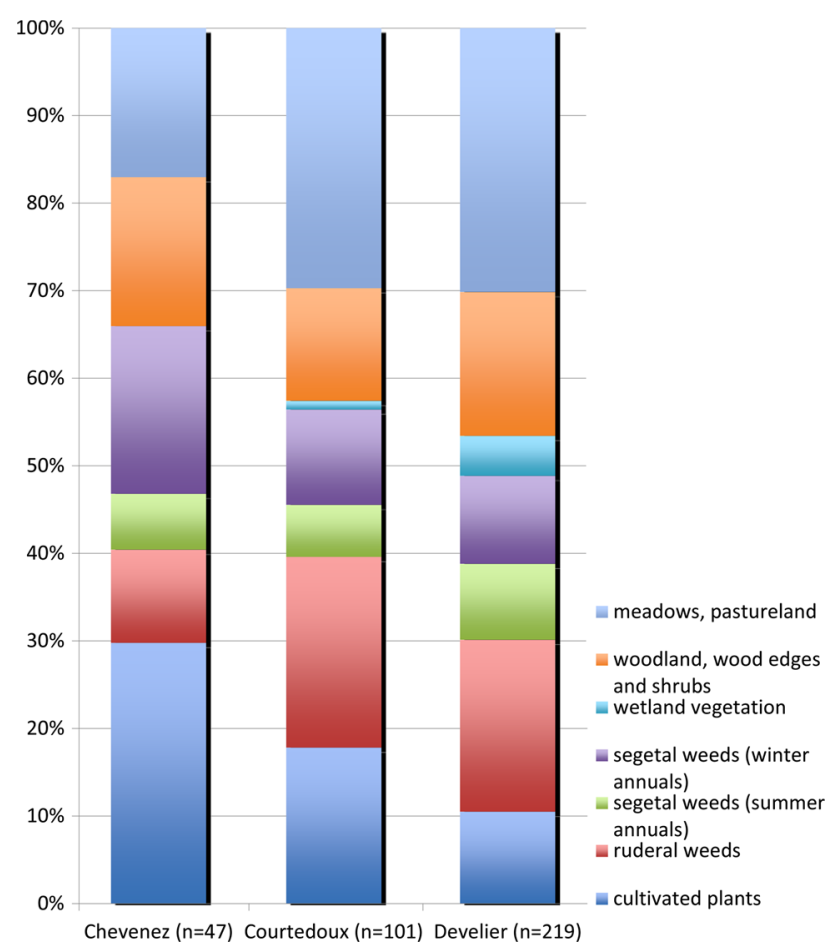

Fig. 3 Wild plant taxa grouped according to ecological habitat types, (based on groupings of phytosociological classes after Ellenberg and Leuschner 2010); $\mathrm{n}=$ number of taxa processing. Fruits and nuts were relatively rare. They include mainly wild gathered plants and comprise Corylus avellana (hazel), Sambucus sp. (elder), Fragaria vesca (wild strawberry) and Rubus fruticosus/idaeus (blackberry/ raspberry).

A major part (around $30 \%$ ) of the remaining wild plants comes from taxa typical of meadows and pastureland (Fig. 3). They include a large number of grasses like $A g$ rostis sp. (bent), Cynosurus cristatus (crested dog's-tail) and Phleum sp. (cat's-tail), as well as Leucanthemum vulgare (oxeye daisy), Plantago lanceolata (ribwort plantain) and Prunella vulgaris (self-heal). Taxa typical of arable land represent about $10 \%$ of all remains and are dominated by Bromus secalinus (chess grass), Bupleurum rotundifolium (thorow-wax), Agrostemma githago (corncockle) and Vicia div. sp. (vetches). The few woodland taxa are essentially represented by fruits and seeds of Abies alba and Fagus sylvatica. It indicates that the local forest was of the Abieti-Fagetum type. However Mercurialis perennis (dog's mercury) and Scrophularia nodosa (common figwort) were also found.

The plant remains from Courtedoux-Creugenat

A total of 39,913 carbonised plant macroremains were counted, representing 158 taxa. The mean concentration was 47 remains per litre of sediment, but this varied greatly between the hut floors, from 6 (Hut floor 113) to 163 (Hut floor 4) remains per litre.

Cereals $(3,511)$ make up a third of the taxa represented on the hut floors, and apart from $H$. vulgare all of the cereals cultivated during the early medieval period in westcentral Europe have been identified from this site. Avena sp., T. aestivum, T. spelta and S. cereale are the best represented, followed in diminishing importance by $T$. monococcum and $T$. dicoccon. Small numbers of P. miliaceum and Setaria italica were also found. Twothirds $(66 \%)$ of the cereal remains were grains, while the rest $(34 \%)$ were cleaning residues, mainly chaff. 
The other cultivated plants were poorly represented. These include Lens culinaris, Juglans regia (walnut), Prunus domestica (plum), Brassica div. sp., and a few condiments, including Anethum graveolens and Coriandrum sativum. Some of this group were present in significant numbers, including L. culinaris and J. regia.

Among the edible and medicinal wild plants identified, the fruits and nuts of Corylus avellana and various species of Sambucus were the most common, while remains of Fragaria vesca, Malus sp. (apple), Rubus idaeus and Atropa belladonna (deadly nightshade) were much rarer. These taxa all usually grow in open woodland.

The great majority $(54 \%)$ of remains from wild taxa (Fig. 3) that can be placed in an ecological group are typical of meadows and pastures; with abundant Phleum sp. Plants typical of arable land are dominated by Bromus sp., Agrostemma githago and Fallopia convolvulus, while ruderals include various taxa of Rumex and Chenopodium, and Polygonum aviculare.

\section{The plant remains from Chevenez-Lai Coiratte}

Unfortunately, the loss of sieve fractions smaller than $1 \mathrm{~mm}$ from the samples given to the archaeobotanists has led to a significant underrepresentation of many taxa in the results table. An inevitable consequence is that the interpretations are less precise. The analysed sediments yielded 15,480 carbonised plant macroremains from 73 taxa. In general, concentrations were of 20 or more remains per litre, varying considerably from 32 remains per litre in sunken-floored huts to $\leq 10$ remains per litre in the other structures such as metal working areas and places for the disposal of metal working waste.

All of the cereals cultivated during the early medieval period in west-central Europe were present. The best represented cereals were Avena $\mathrm{sp}, T$. aestivum, $T$. spelta and $S$. cereale, while $H$. vulgare and $P$. miliaceum were fairly rare. Apart from T. spelta, chaff fragments from grain cleaning residues (193) were rare by comparison to the grains $(3,943)$ and represented just $5 \%$ of the total remains identifiable to cereals. This might be due to the site functioning as a workplace zone rather than as a settlement, or it could have been caused by the loss of the finest sieve fractions after sample processing. The other cultivated plants include L. culinaris and Prunus domestica, represented by a complete plum stone and three characteristic fragments. Fragments from other fruit stones (69) could only be identified as belonging to the group Prunus domestica/insititia/spinosa. Rare specimens of $C$. sativum, Brassica sp., V. sativa (common vetch) and L. usitatissimum complete the list of cultivated plants.

Edible wild plants, which were either arable weeds or came from the surrounding area, include Fallopia convolvulus, Galium div. sp. and Rumex div. sp. which were eaten for their leaves, and Corylus avellana and Sambucus div. sp. which were collected for their fruit and nuts.

The largest number of remains from wild plants came from Poaceae, especially Bromus sp. and also from Vicia div. sp., some of which are arable weeds. Remains from taxa typical of meadows and pasture or of damp habitats were only poorly represented.

\section{Discussion}

Field and garden crops

In Merovingian times cultivated plants mainly consisted of a great variety of cereals, but also included legumes as well as oil and fibre producing plants. The importance of A. sativa and Avena sp. as the principal cereal at all three sites is remarkable, with $64 \%$ at Develier-Courtételle, $30 \%$ at Courtedoux-Creugenat and $34 \%$ at Chevenez-Lai Coiratte (Fig. 2). Triticum spelta and T. aestivum also played an important role, as can be seen at other sites from this period (Jacomet and Brombacher 2009; Brombacher et al. 1997; Rösch 2008). Triticum monoccocum constituted a remarkable part of the cereal remains, especially at Develier-Courtételle, while $S$. cereale also attained a certain importance.

During Roman times, Avena played only a minor role in the subsistence economy of central Europe, but the advent of the early medieval period saw oats become an important cereal crop. The wheat species show significant variations between the sites: at Develier-Courtételle, situated within the Delémont basin, T. spelta was the most common, while in the Ajoie region T. aestivum was more abundant. This gives the impression that naked wheat was more important in the Ajoie plain, which has a more favourable climate due to its opening onto the Alsace and Bourgogne regions, than at Develier-Courtételle, which is located within the Jura mountains. By contrast, hulled wheat was more frequent at Develier-Courtételle than in the two sites from the Ajoie, in agreement with Rösch et al. (1992), who have detailed how during this period T. monococcum was more important in areas with unfavourable climates.

In general, $S$. cereale was only feebly represented. It reached a maximum of $6 \%$ at Courtedoux-Creugenat, of which $75 \%$ was from chaff, while at Develier-Courtételle rye was also mostly represented by chaff $(94 \%)$. It is only at Chevenez-Lai Coiratte that more grains (56) than chaff (12) have been found, which could be due to the loss of sieve fractions smaller than $1 \mathrm{~mm}$. Rye was already present in the region during Roman times, mainly in the 3rd century AD, as shown by regular finds at Augusta Raurica on 

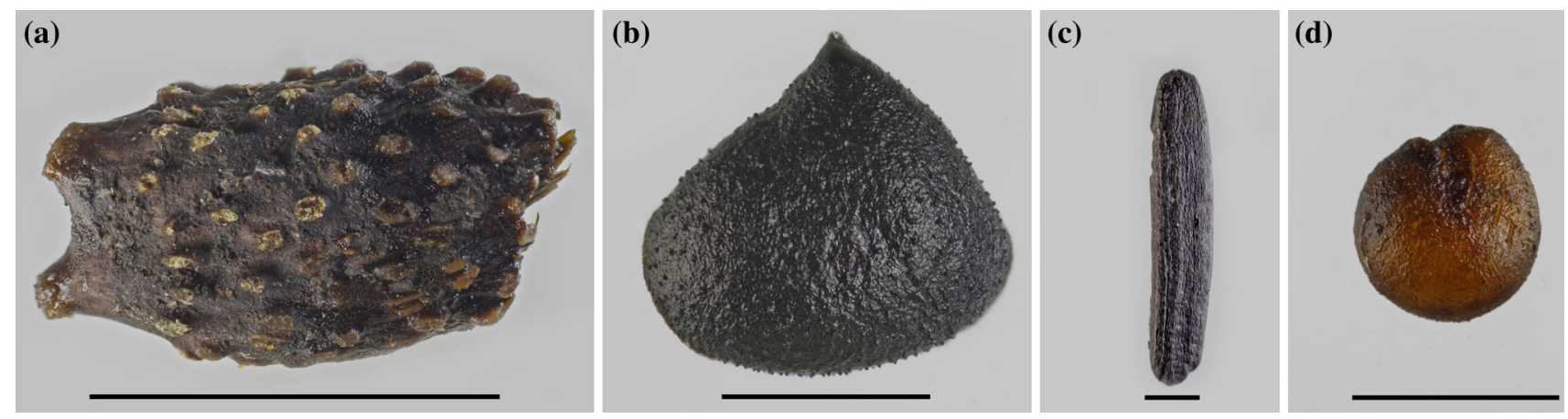

Fig. 4 Some plant remains from Develier-Courtételle: a Xanthium strumarium; b Spergula arvensis; c Claviceps sp.; d Reseda luteola (photos by G. Haldimann, La Chaux-de-Fonds). Scales $\mathbf{a} 1 \mathrm{~cm}$, b-d $1 \mathrm{~mm}$

the upper Rhine upstream of Basel (Jacomet and Brombacher 2009).

The relative unimportance of $H$. vulgare, $T$. dicoccon and the two types of millet is striking, as these cereals were more widespread during Roman times and in the Migration Period (late 4th-5th centuries AD). Triticum dicoccon seems to have become less important at the end of the Roman era (Kreuz 2004), while $H$. vulgare declined from the start of the Merovingian period (Rösch 2008). The virtual absence of $H$. vulgare from the three investigated sites is remarkable. This can also be observed at other Merovingian sites in Switzerland (Brombacher et al. 1997), but not in southern Germany where barley appears regularly and is often dominant (Rösch 1997). By contrast, P. miliaceum and Setaria italica are also very rare at other sites from this period, although this might be linked to the fact that millets are much better represented as waterlogged macroremains at sites with suitable sediments (Rösch et al. 1992). There seems to be only a small chance that millets would become carbonised, due to the very narrow temperature range at which this happens for them (Märkle and Rösch 2003).

Four species belonging to another important group of cultivated food crops, the legumes, were also identified. The most common of these was L. culinaris, noted at all three sites, which dominates the legumes as it does at other Merovingian sites. Pisum sativum and V. faba (broad bean) appeared in smaller numbers and were obviously of lesser importance. The fourth species, V. sativa, was only found in small numbers at Develier-Courtételle and ChevenezLai Coiratte. This legume only began to play a more important role during the medieval period (Jacomet and Brombacher 2009). It was, however, not used as a foodstuff for humans, but for feeding animals (Zohary et al. 2012, p. 95).

Oil and fibre producing plants

Among the oil and fibre producing plants, remains of L. usitatissimum, Cannabis sativa and Papaver somniferum have been found, although not all of them were present at all three sites. A concentration of material with all three species was found in the waterlogged layers at DevelierCourtételle. For flax, in addition to the seeds, a good number of capsules and small stems have also been found (Brombacher 2008). The archaeological material from this site also clearly indicates that textile production was taking place (Federici-Schenardi and Fellner 2004).

The presence of 74 seeds of Spergula arvensis is also of note. A form with large seeds exists as a typical weed of flax cultivation (Latałowa 1998, p. 102) and this has been found at Develier-Courtételle (Fig. 4), showing that these plants must have been brought to the site together with harvested flax. All of these seeds were found in the zone with waterlogged sediments. Cultivated flax has also been identified at Chevenez-Lai Coiratte but is absent from Courtedoux-Creugenat.

In contrast to flax, the growing and processing of Cannabis is also confirmed by pollen analysis at DevelierCourtételle (Wick 2008, p. 96). High values (up to $40 \%$ ) of Humulus-Cannabis-type pollen in the archaeological levels indicate that these fibre producing plants were processed within the settlement. Small amounts of Brassica seeds might suggest its use as an oil-producing plant, but the low frequencies found make this hypothesis rather implausible. The same arguments can be used for Camelina sativa, which was also only present in low numbers.

Fruits and nuts, vegetables and spices

Among the cultivated fruits, remains of Prunus domestica, Malus sp. and J. regia have been identified. These indicate local cultivation, which suggests a continuity in fruit growing from Roman times until the early medieval period north of the Alps (Willerding 2002). These records provide us with evidence of the first orchards and gardens, where various plants were cultivated or planted which had been first introduced during the Iron Age or the Roman period into the region under discussion here (Jacomet and 
Brombacher 2009). But these rare finds are by no means comparable with the range of fruit growing described for this period in, for example, the south of France (Ruas 2005). Nor are these results comparable with the great densities of macroremains found in the latrines of the medieval period (Brombacher et al. 1997; Sillmann 2002; Märkle 2005). An exception is early medieval Douai in northern France, where great numbers of Prunus domestica fruit stones were found (Van Zeist et al. 1994).

Fruits from wild sources that must have been gathered in the surrounding area, include Fragaria vesca, Rubus fruticosus, $R$. idaeus, Sambucus sp., Corylus avellana and Prunus spinosa, although cultivation of the last two species cannot be totally excluded. C. avellana, for example, is mentioned in the late 8th/early 9th century capitulary Capitulare de villis vel curtibus imperialibus (Vogellehner 1989).

The absence of any remains from Vitis (grapes) may be due to local climatic conditions at the three sites, because this region is hardly suitable for the cultivation of vines, unlike Bourgogne (Gauthier 2004), the Basel region (Brombacher et al. 1997) or the southern slopes of the Jura (Brombacher 1999) from where grape remains have been found. As the plant remains provide a picture of local agricultural production, the lack of any grape pips thus reflects the absence of viticulture in the region around the investigated sites.

Proof of the use of plants as vegetables is problematic because their remains tend to preserve badly and are difficult to identify, so it is no surprise to have so few identified remains of vegetables and spices. Only the rare remains of condiments such as Anethum graveolens and Apium graveolens, which may have been cultivated, have been found, especially at Courtedoux-Creugenat and Develier-Courtételle. Of note is the spice C. sativum, introduced by the Romans, which was found at all three sites. In contrast to these scanty remains, some sites in southwest Germany have provided evidence of cultivated vegetables, spices and fruits, which indicates that largescale gardening was taking place in early medieval times (Rösch 1999, 2006, 2008). Finally, the remains of other herbs, like Origanum vulgare, Verbena officinalis and Marrubium vulgare, show that these were probably gathered from the wild.

Other useful plants

Linked with the evidence for the processing of vegetable fibres are the remains of various plants that could have been used for dyeing and carding (Cardon and du Chatenet 1990), like $R$. luteola and X. strumarium, as well as D. fullonum, Hypericum perforatum and various species of Galium. The rare seeds of Dipsacus are particularly interesting, as Fuller's teasel (the cultivar group D. fullonum Sativus Group; syn. D. sativus) was also formerly widely used in carding and textile processing, usually of wool, providing a natural comb for cleaning, aligning and raising the nap on fabrics (Hall 1992).

A few species that may have been used as medicinal plants merit special attention. These include Atropa belladonna, Conium maculatum and Hyoscyamus niger. A. belladonna, a plant characteristic of woodland clearings, is of note as it was found at all three sites. The main active agent, hyoscyamine, is also present in other members of the Solanaceae family, like Hyoscyamus niger. Historically, belladonna was used as an abortifacient, against gout and rabies, as an aphrodisiac that dilated the pupils and in ointments for witches. Interestingly, belladonna was also used as a poison on arrow heads during hunting (Lewis 1923).

Two other taxa can cause serious unintentional poisoning, as they can often end up in food through the intermediary of cereals. Claviceps sp. (ergot fungus), which grows on rye and is very toxic, was found in several samples at Develier-Courtételle. These finds are among the oldest examples from the post-Roman period in Switzerland. The toxic seeds of Agrostemma githago (corncockle) are difficult to separate from harvested cereals so they were often milled together by mistake, which could also lead to poisoning.

Another plant that may have been used, Humulus lupulus, can grow naturally in alluvial woods. Evidence for this species includes both the more than 200 seeds identified at Develier-Courtételle and pollen analyses from the Delémont valley (Wick 2008). According to written sources, cultivation of Humulus did not start before the 9th century AD (Behre 1999). This suggests that the macroremains came from wild hops gathered near to the settlement.

\section{Wild plants and environments}

Of the wild plants recovered from the three sites, around $50 \%$ were of taxa typical of woodlands, hedges and grassy places (Fig. 3), while the other $50 \%$ were from taxa that come from habitats affected by human influence, such as ruderals and segetals (arable weeds).

Pollen analyses in the Delémont valley (Wick 2008; Rachoud-Schneider 1993) show that iron working was consuming enormous quantities of wood and that the forests around the sites had been largely cleared. The absence of rises in pioneer trees like Betula, Alnus and Corylus suggests that human activities prevented any regrowth of woodland. Increased values of plants typical of meadows and pastures in the pollen diagrams indicate that they had colonised much of the area previously occupied by woodland. 
Macroremains of A. alba (needles) and of $F$. sylvatica, especially at Develier-Courtételle, demonstrate the presence of shaded forest similar to that found in this region today. The regular presence of forest fruits like $R$. idaeus and $R$. fruticosus, Sambucus sp., Fragaria vesca, Rosa sp. and Corylus avellana confirm the importance of these fruits in the human diet. The few woodland taxa at CourtedouxCreugenat and Chevenez-Lai Coiratte all normally grow beneath a fairly open tree canopy, which suggests intensive woodland management linked with either a developed agro-pastoral system (Courtedoux-Creugenat) or a metal working industry greedy for wood (Chevenez-Lai Coiratte). At Develier-Courtételle, the macroremains of Salix sp. and Alnus sp., typical of alluvial woods, as well as the marsh and aquatic plants Chara div. sp., Typha sp., Alisma sp. and Mentha sp. demonstrate the closeness of the site to damp or wet habitats such as alluvial zones or streams.

The remains of plants from meadows and pastures at all three sites indicate rather damp soils rich in nitrogen, which produced fodder for livestock. The plants include various species of Trifolium (clover) and taxa such as Plantago lanceolata, Cynosurus cristatus, Phleum pratense, Prunella vulgaris and Potentilla reptans, some of which were present in large numbers. The significant presence of plants typical of trampled zones and tolerant of grazing is suggestive of intensively grazed pasture. These areas, which seem for the most part to have had damp lowland soils and supported the plant communities Molinetalia and Arrhenatheretalia (Ellenberg 2001), must have been situated very near to the sites. The exploitation of woodland margins and hedges also seems to have been important.

There were few remains from plants typical of dry meadows and pastures that belong to the Brometalia plant community described by (Ellenberg 2001, subatlantic semi-dry and dry grassland). This suggests that places with dry grassland were rare around the three sites. Species typical of this group that were recorded include Ajuga genevensis, Anthyllis vulneraria, Medicago lupulina, Pimpinella saxifraga, Prunella grandiflora and Sanguisorba minor. They belong to the phytosociological group of true semi-dry grassland (Mesobromion) typical of moderately dry locations, while taxa characteristic of subatlantic dry grassland (Xerobromion), which grow in places with thin, truly dry soils, were almost entirely absent. These meadows, precious refuges for flora and fauna, which were very common in the Jura until the first half of the 20th century, do not seem to have been well developed at this time.

Among the weeds, the majority are linked to autumnsown cereal crops, with 24 taxa. Many grow on alkaline soils and belong to the phytosociological group Caucalidion (Ellenberg 2001). Among these, Bupleurum rotundifolium, Caucalis platycarpos, Orlaya grandiflora and Sherardia arvensis are of special interest, while Euphorbia exigua and Valerianella rimosa also belong to this group. In the Basel region of northwest Switzerland there is evidence for all of these taxa since the late Bronze Age (Jacomet and Brombacher 2009). Other weeds of winter cultivation, such as Agrostemma githago, Bromus secalinus, Centaurea cyanus, Scleranthus annuus and wild vetches, rather indicate neutral soils belonging to the plant community Aperetalia.

Remains from weeds of spring sown crops and hoed crops, belonging to the phytosociological group Chenopodietea, are less numerous, with 18 taxa. Of note are the relatively common Aethusa cynapium, Chenopodium polyspermum, Euphorbia helioscopia, Polygonum persicaria and Thlaspi arvense, and the presence at DevelierCourtételle of Spergula arvensis, a typical weed of flax cultivation.

Ruderal plants are well represented with 50 taxa. These cannot, however, be accurately associated with any phytosociological group, nor can they be reliably separated from weeds of spring cultivation and hoed crops. They comprise both annual and perennial plants, being represented above all by Lapsana communis, Polygonum aviculare, Urtica dioica and Verbena officinalis (Table 3), which principally grow on damp, nitrogen rich soils. There is also evidence for some plants of drier and poorer soils (Marrubium vulgare, Saponaria officinalis), as well as vegetation of trodden places like Plantago major. Other ruderals are Hyoscyamus niger and X. strumarium, which both have medicinal properties and can be used for dyeing.

\section{Conclusions}

As usually seen at so-called "producer sites", the plant macroremains at the three study sites included a wide variety of cultivated plants, especially cereals and legumes (Brombacher et al. 2013). At Develier-Courtételle in particular, the production of vegetable fibres was evidently of great importance, as shown by the high frequencies of flax and hemp.

Compared to other contemporary sites in Switzerland, northeastern France and southern Germany, there are only small differences in the spectra of crop plants from the 4th to the 6th century AD. However the relative proportions of these crop plants vary quite significantly, which could indicate differing significance of the individual taxa at the studied sites. Analyses from many different sites, based on a sufficiently large numbers of samples, are therefore required to obtain a more precise image of the importance of different crops. 
Table 3 Ruderal and weed remains found at the three sites

\begin{tabular}{|c|c|c|c|c|c|}
\hline Site & & 1 & 2 & 3, carb. & 3, waterl. \\
\hline \multicolumn{6}{|l|}{ Ruderal weeds } \\
\hline Arctium sp. & Fruit & & & & 27 \\
\hline Arenaria serpyllifolia & Seed & & & & 25 \\
\hline Artemisia $\mathrm{sp} . /$ vulgaris & Fruit & & $35 / 4$ & & \\
\hline Barbarea vulgaris/cf. sp. & Seed & & & & $1 / 3$ \\
\hline Chenopodium album/ficifolium/sp. & Seed & $/ / 1$ & $23 / / 82$ & $8 / 2 / 67$ & $138 / 25 / 412$ \\
\hline Cirsium arvense/vulgare & Fruit & & & & $4 / 12$ \\
\hline Conium maculatum & Fruit & & & & 12 \\
\hline Daucus carota & Fruit & & 14 & 4 & 117 \\
\hline Digitaria ischaemum & Fruit & & & 7 & 2 \\
\hline Dipsacus fullonum/sp. & Fruit & & & & $42 / 1$ \\
\hline Epilobium hirsutum/sp. & Seed & & & $/ 1$ & $13 / 6$ \\
\hline Euphorbia platyphyllos & Seed & & & & 24 \\
\hline Galeopsis tetrahit & Fruit & & & & 28 \\
\hline Galium aparine & Fruit/pod & 69 & 3 & 133 & \\
\hline Hyoscyamus niger & Seed & & & 11 & 6 \\
\hline Lapsana communis & Fruit & & 5 & 96 & 259 \\
\hline Malva neglecta & Fruit & & & & 6 \\
\hline Marrubium vulgare & Fruit & & & & 49 \\
\hline Melilotus altissima/officinalis & Seed & & & $1 / 2$ & \\
\hline Pastinaca sativa & Fruit & & & & 1 \\
\hline Picris sp. & Fruit & & 6 & & 1 \\
\hline Plantago major & Seed & & 4 & 16 & 400 \\
\hline Роа аппиа & Fruit & & 1 & 2 & \\
\hline Polygonum aviculare & Fruit & 1 & 47 & 68 & 412 \\
\hline Ranunculus repens & Fruit & & 10 & 72 & 489 \\
\hline Rumex conglomeratus/pulcher & Fruit & & $1 / 4$ & & 1 \\
\hline$R$. crispus vel obtusifolius & Fruit & 73 & 196 & 17 & 2 \\
\hline Saponaria officinalis & Seed & & & & 2 \\
\hline Silene alba & Seed & & & 5 & 28 \\
\hline Sisymbrium sp. & Seed & & 3 & & \\
\hline Sonchus arvensis/asper/oleraceus & Fruit & & & & $52 / 52 / 21$ \\
\hline Urtica dioica & Seed & & 1 & & 3979 \\
\hline Verbascum sp. & Seed & & & & 1 \\
\hline Verbena officinalis & Fruit & & 1 & 10 & 261 \\
\hline \multicolumn{6}{|l|}{ Segetal weeds, spring cultivation } \\
\hline Aethusa cynapium & Fruit & & & & 114 \\
\hline Anagallis arvensis & Seed & & & 4 & 39 \\
\hline Atriplex patula & Seed & & & & 1 \\
\hline Brassica rapa & Seed & & 1 & & 25 \\
\hline Capsella bursa-pastoris & Seed & & & & 22 \\
\hline Chenopodium polyspermum & Seed & & 20 & & 22 \\
\hline Echinochloa crus-galli & Fruit & & & 15 & \\
\hline Euphorbia helioscopia & Seed & & & 5 & 6 \\
\hline Lamium purpureum & Fruit & & & & 2 \\
\hline cf. Lolium temulentum & Fruit & & 1 & & \\
\hline Polygonum persicaria & Seed & 97 & 17 & 64 & 76 \\
\hline Portulaca oleracea & Seed & & & 1 & \\
\hline Setaria glauca/verticillata vel viridis & Fruit & $/ 1$ & & $3 / 17$ & $6 / 105$ \\
\hline Sinapis arvensis/sp. & Seed & & & $2 / 83$ & $1 /$ \\
\hline Solanum nigrum & Seed & & & & 22 \\
\hline Spergula arvensis & Seed & & & & 74 \\
\hline Stellaria media & Seed & & 19 & 3 & 101 \\
\hline Thlaspi arvense & Seed & & & & 4 \\
\hline Vicia sp. & Seed & 1,093 & 430 & 209 & 1 \\
\hline \multicolumn{6}{|l|}{ Segetal weeds, winter cultivation } \\
\hline Agrostemma githago & Seed/caps. & 86 & 113 & 34 & 20 \\
\hline Asperula arvensis & Fruit & & 1 & 0 & \\
\hline Avena fatua & Chaff, floret & & & 224 & \\
\hline Bromus secalinus/sp. & Fruit & $/ 486$ & /366 & $491 / 24$ & \\
\hline Bupleurum rotundifolium & Fruit & & 3 & 95 & 252 \\
\hline Caucalis platycarpos & Fruit & & 4 & & \\
\hline Centaurea cyanus & Fruit & & & & 30 \\
\hline Euphorbia exigua & Seed & & & & 4 \\
\hline Fallopia convolvulus & Seed & 67 & 84 & 63 & 38 \\
\hline Galium aparine vel spurium/spurium & Fruit & $2 / 1$ & & $/ 1$ & $/ 9$ \\
\hline Orlaya grandiflora & Fruit & & & 3 & 41 \\
\hline Scleranthus annuus & Fruit & 4 & 25 & 1 & 6 \\
\hline Sherardia arvensis & Fruit & 1 & 3 & 99 & \\
\hline Silene gallica & Seed & & & 2 & \\
\hline Stachys annua vel arvensis & Fruit & & & & 3 \\
\hline Valerianella dentata/locusta/rimosa & Fruit & & $4 / /$ & $35 / 5 /$ & $244 / 1 / 6$ \\
\hline Vicia angustif./hirsuta/tetrasperma/villosa & Seed & $2 / 1 / 10 /$ & $/ 4 / 10 /$ & $1 / 13 / 73 /$ & $/ / 3 / 2$ \\
\hline Viola tricolor & Seed & & & & 2 \\
\hline
\end{tabular}


The absence of exotic plants seems to indicate that the inhabitants of these three sites had a rather modest social status, which is not surprising in this rural setting, at the frontier between the diverse influences of the Kingdom of Burgundy and Alamannia, where the industries of iron working and textile production were the way of life.

The increase in the effects of human activities seen in pollen profiles spread across the Jura mountains during the 7th century AD (Gauthier 2004) can also be seen in the areas covered by the sites studied here, with the available diagrams showing major forest clearance (Wick 2008), especially around settlements.

People settled where the exploitation of natural resources such as wood, iron ore etc. was profitable and where the feeding of the population was possible from farming. A decline of fir in pollen diagrams matched by a rise in plants of meadows and pasture probably indicates an expansion and intensification of cattle rearing.

Acknowledgments This work was supported by the Office de la culture du Canton du Jura. The text was improved with the help of suggestions from S. Jacomet, U. Maier and an anonymous reviewer. We would also like to thank N. Thew for the English translation and his useful comments on the manuscript.

\section{References}

Behre K-E (1999) The history of beer additives in Europe-a review. Veget Hist Archaeobot 8:35-48

Brombacher C (1999) La Neuveville. L'histoire du paysage médiéval révélée par l'étude des macrorestes végétaux. Archäologie im Kanton Bern 4:277-284

Brombacher C (2008) Les macrorestes végétaux, reflets des pratiques agricoles, de l'alimentation et de l'environnement. In: Guélat M, Brombacher C, Olive C, Wick L (eds) Develier-Courtételle. Un habitat rural mérovingien 4: Environnement et exploitation du terroir. (Cahier d'archéologie jurassienne 16) Office de la culture et Société jurassienne d'Emulation, Porrentruy, pp 103-141

Brombacher C, Jacomet S, Kühn M (1997) Mittelalterliche Kulturpflanzen aus der Schweiz und Liechtenstein: eine Übersicht der archäobotanischen Nachweise. In: De Boe G, Verhaeghe F (eds) Environment and subsistence in Medieval Europe. I.A.P. Rapporten, Brügge, pp 95-111

Brombacher C, Guélat M, Thew N (2013) Transformations du cadre naturel et développement de l'agriculture dans la chaîne jurasienne, de l'époque romaine à la fin du haut Moyen Âge. Aspects archéobotaniques, malacologiques et géologiques. In: Richard A, Schifferdecker F, Mazimann J-P, Bélet-Gonda C (eds) Deuxièmes journées archéologiques frontalières de l'Arc jurassien (Annales littéraires de l'Université de Franche-Comté. Série "Environnement, sociétés et archéologie" 17). Presses Universitaires de Franche-Comté, Besançon, pp 367-384

Cappers R, Bekker RM, Jans JEA (2006) Digitale Zadenatlas van Nederland (Digital Seed Atlas of the Netherlands). Barkhuis Publishing \& Groningen University Library, Groningen

Cardon D, Du Chatenet G (1990) Guide des teintures naturelles: plantes, lichens, champignons, mollusques et insectes. Delachaux et Niestlé, Neuchâtel, Paris
Ellenberg H (2001) Zeigerwerte von Pflanzen in Mitteleuropa. Goltze, Göttingen

Ellenberg H, Leuschner C (2010) Vegetation Mitteleuropas mit den Alpen in ökologischer, dynamischer und historischer Sicht, 6th edn. Ulmer, Stuttgart

Evéquoz E, Elyaqtine M, Gonda C (2007) Chevenez, Lai Coiratte (Jura, CH): traces d'habitat du haut Moyen Âge et sépulture triple. In: Bélet-Gonda C, Mazimann J-P, Richard A, Schifferdecker $\mathrm{F}$ (eds) Premières journées archéologiques frontalières de l'Arc jurassien (Cahier d'archéologie jurassienne 20). Office de la culture et Société jurassienne d'Emulation, Porrentruy, pp 287-294

Evéquoz E, Eschenlohr L, Deslex C, Elyaqtine M, Bélet-Gonda C (2013) Occupations du Haut Moyen Age à Chevenez: inhumations et atelier métallurgique. (Cahier d'archéologie jurassienne 27). Office de la culture et Société jurassienne d'Emulation, Porrentruy

Federici-Schenardi M, Fellner R (2004) Develier-Courtételle. Un habitat rural mérovingien 1 . Structures et matériaux de construction (Cahier d'archéologie jurassienne 13). Office de la culture et Société jurassienne d'Emulation, Porrentruy

Gauthier E (2004) Forêts et Agriculteurs du Jura. Les quatre derniers millénaires. Presses universitaires de Franche-Comté, Besançon

Guélat M, Brombacher C, Olive C, Wick L (2008) DevelierCourtételle. Un habitat rural mérovingien 4. Environnement et exploitation du terroir (Cahier d'archéologie jurassienne 16). Office de la culture et Société jurassienne d'Emulation, Porrentruy

Hall A (1992) The last teasel factory in Britain, and some observations on teasel (Dipsacus fullonum L. and D. sativus (L.) Honckeny) remains from archaeological deposits. Circaea 9:9-15

Hecker D (2013) L'archéobotanique. In: Evéquoz E, Eschenlohr L, Deslex C, Elyaqtine M, Bélet-Gonda C (eds) Occupations du Haut Moyen Age à Chevenez: inhumations et atelier métallurgique (Cahier d'archéologie jurassienne 27). Office de la culture et Société jurassienne d'Emulation, Porrentruy, pp 99-107

Hosch S, Zibulski P (2003) The influence of inconsistent wet-sieving procedures on the macroremains concentration in waterlogged sediments. J Archaeol Sci 30:849-857

Jacomet S, Brombacher C (2009) Geschichte der Flora in der Regio Basiliensis seit 7500 Jahren: Ergebnisse von Untersuchungen pflanzlicher Makroreste aus archäologischen Ausgrabungen. Mitt Natforsch Ges Basel 11:27-106

Kirchhofer W (1982) Klimaatlas der Schweiz. Bundesamt für Landestopographie, Wabern

Kreuz A (2004) Landwirtschaft im Umbruch? Archäobotanische Untersuchungen zu den Jahrhunderten um Christi Geburt in Hessen und Mainfranken. Ber RGK 85:97-292

Latałowa M (1998) Botanical analysis of a bundle of flax (Linum usitatissimum L.) from an early medieval site in northern Poland; a contribution to the history of flax cultivation and its field weeds. Veget Hist Archaeobot 7:97-107

Lewis L (1923) Die Pfeilgifte. Johann Ambrosius Barth, Leipzig

Märkle T (2005) Nutrition, aspects of land use and environment in medieval times in southern Germany: plant macro-remain analysis from latrines (late 11th-13th century $\mathrm{AD}$ ) at the town of Überlingen, Lake Constance. Veget Hist Archaeobot $14: 427-441$

Märkle T, Rösch M (2003) Verkohlungsversuche an Kulturpflanzen. Experimentelle Archäologie in Europa 2:73-80

Moor M (1952) Die Fagion-Gesellschaften (Buchen-, TannenBuchen- u. Ahornwälder) im Schweizer Jura (Beiträge zur geobotanischen Landesaufnahme der Schweiz 31). Huber, Bern

Pearsall DM (2000) Paleoethnobotany. A handbook of procedures, 6th edn. Academic Press, San Diego 
Rachoud-Schneider A-M (1993) Contribution à l'histoire de la végétation tardi- et postglaciaire de la vallée de Delémont à partir des données de la palynologie. In: Guélat M, RachoudSchneider A-M, Eschenlohr L, Paupe P (eds) Archives palustres et vestiges de l'Age du Bronze entre Glovelier et Boécourt (JU, Suisse) (Cahier d'archéologie jurassienne 4). Office de la culture et Société jurassienne d'Emulation, Porrentruy, pp 53-74

Rösch M (1997) Ackerbau und Ernährung. Pflanzenreste aus alamannischen Siedlungen. In: Archäologisches Landesmuseum Baden-Württemberg (ed) Die Alamannen. Theiss, Stuttgart, pp 323-330

Rösch M (1999) Archäobotanische Belege für frühmittelalterlichen Gartenbau in Südwestdeutschland. In: Rolle R, Andraschko FM (eds) Frühe Nutzung pflanzlicher Ressourcen (Hamburger Werkstattreihe zur Archäologie 4). LIT-Verlag, Hamburg, pp 61-69

Rösch M (2006) Die Gärten der Alamannen-Bodenfunde zeigen ein neues Bild von Pflanzenanbau nördlich der Alpen. Denkmalpfl Bad-Württ 35:166-171

Rösch M (2008) New aspects of agriculture and diet of the early medieval period in central Europe: waterlogged plant material from sites in south-western Germany. Veget Hist Archaeobot $17: 225-238$

Rösch M, Jacomet S, Karg S (1992) The history of cereals in the region of the former Duchy of Swabia (Herzogtum Schwaben) from the Roman to the Post-Medieval period: results of archaeobotanical research. Veget Hist Archaeobot 1:193-231

Ruas M-P (2005) Aspects of early medieval farming from sites in Mediterranean France. Veget Hist Archaeobot 14:400-415
Sillmann M (2002) Botanische Grossreste mittelalterlicher und frühneuzeitlicher Latrinen und Gruben aus Freiburg im Breisgau. In: Galiato L, Löbbecke F, Untermann M (eds) Das Haus “Zum roten Basler Stab" (Salzstrasse 20) in Freiburg in Breisgau (Forsch Ber Archäol Mittelalters Bad-Württ 25). Theiss, Stuttgart, pp 623-770

Van der Veen M, Fieller NRJ (1982) Sampling seeds. J Archaeol Sci 9:287-298

Van Zeist W, Woldring H, Neef R (1994) Plant husbandry and vegetation of early medieval Douai, northern France. Veget Hist Archaeobot 3:191-218

Vogellehner D (1989) Les jardins du Haut Moyen Age (VIIIe -XIIe siècles). Flaran 9:11-40

Wick L (2008) (avec la collaboration d'Anne-Marie RachoudSchneider) Les analyses polliniques. In: Guélat M, Brombacher C, Olive C, Wick L (eds) Develier-Courtételle. Un habitat rural mérovingien 4. Environnement et exploitation du terroir (Cahier d'archéologie jurassienne 16). Office de la culture et Société jurassienne d'Emulation, Porrentruy, pp 85-102

Willerding U (2002) Obst und Obstbau. In: Beck H, Geuenich D, Steuer H (eds) Reallexikon der Germanischen Altertumskunde, vol 21. De Gruyter, Berlin, pp 517-523

Zohary D, Hopf M, Weiss E (2012) Domestication of plants in the Old World. The origin and spread of domesticated plants in south-west Asia, Europe and the Mediterranean Basin, 4th edn. Oxford University Press, Oxford 